\title{
CONCEPTIONS OF THE POLITICAL IN ISLAMIC THOUGHT: RECONCILING LEGAL AND PHILOSOPHIC APPROACHES TO SIYĀSAH
}

\author{
Tengku Ahmad Hazri*
}

\begin{abstract}
Political societies and states may undergo constitutional transformations. However, if Islamic constitutional jurisprudence is to address adequately the problem of constitutional shifts then both classical and modern reformist juridical approaches to siyāsah must be reconciled with the approach of the Muslim philosophers, in order to secure the former's conceptual coherence when analysing shifts in constitutional structures.
\end{abstract}

\section{Introduction: Two Constitutions}

Political Societies wherever they may be found (conventionally referred to as 'states') and insofar as they are recognised as such, will have constitutions whether or not they are written - for a constitution is simply the "form of the state". This conception of constitution as conceived by Plato, Aristotle and the Muslim philosophers, understands 'constitution' to be the form of the 'political society' - not a written document. Yet even when the society adopts a written constitution, this does not mean that its 'unwritten' constitution disappears. It is our thesis that insofar as a society adopts a written constitution, it can be said to be in possession of two constitutions: the written and the unwritten. While not all societies will have a written constitution (Britain and Israel are two such examples), they nevertheless will have an unwritten constitution, for otherwise the society hardly qualifies as a political society to start with, much less a state. ${ }^{1}$

At the non-state level of the unwritten constitution (i.e. outside of the written constitution), there exists the possibility of identifying several nation-states as belonging to a single civilisational community expressed among others in the domain of culture and thought through language by key concepts and terms. ${ }^{2}$ Furthermore, a constitution may change or transform (e.g., from aristocracy to democracy, or from democracy to tyranny), meaning that its structure undergoes change due to transformations in social attitudes or shifts in centres of power and authority. Therefore there are both good constitutions and bad constitutions - in contrast to the prevalent view that sees a constitutional government as necessarily good or even as the 'ideal' government, while a 'bad' government is depicted as 'un-constitutional' or 'non-constitutional'.

A constitutional crisis may occur when there is mismatch, asymmetry or 
antagonism between the written and the unwritten constitution, when the principles and ethos embodied in the written constitution do not - or no longer - reflect the unwritten constitution. The 'unwritten' constitution is the form, structure or architecture of the political community, which organically grows from within the community itself, shaped and defined by its adherence to religion, custom, culture, norms, rules, conventions and related factors independent of the 'state'. While the written constitution may be fixed, objectively defined, and relatively stable, the unwritten constitution is more flexible and may undergo shift or transformation, independent of official constitutional amendments. Indeed it is a change in the unwritten constitution that often leads to the amendments to the written constitution.

The 'two constitutions' theory resonates especially strongly in the contemporary Muslim world where one frequently sees written constitutions adopted which hardly reflect the unwritten constitution. The constitution may define the people as one 'nation' - but the so-called 'nation' in fact comprises sectarian groups divided along tribal, linguistic, cultural, ethnic and religious lines whose only reason for being joined together was to facilitate colonial administration. The constitution may define 'secularism' to be the official ideology of the state when in fact the Shari'ah occupies a foremost role in society, while religious institutions and scholars play pivotal function in the regulation and administration of social order. Seen in this light, the written constitution may be seen as an attempt to rewrite the unwritten constitution, a project towards social engineering.

Even in more stable societies the disjuncture between the written and unwritten constitution may be seen. The written constitution may declare itself to be a socialist state, endowing the state with the task to ensure public welfare and social justice, even to the point of direct state involvement, or through governmentlinked companies (GLCs), in providing basic welfare for the people such as education, health care, transportation and other development infrastructures. Thus the Constitution of Mexico stipulates that the state shall be in control of areas of priority in the economy and that monopolies are prohibited. But if and when the private sector offers far superior services - even within access of the financially disadvantaged - society will readjust itself accordingly so that the state's "socialist" commitment dwindles into insignificance, and no longer reflects the unwritten constitution.

This widespread phenomenon of the 'two constitutions' requires adequate responses; in particular, how does one analyse the shifts and changes in constitutional structures? And how may one produce a constitutional jurisprudence able to accommodate and anticipate the various legal and political arrangements arising from such transformations? The Muslim jurists (fuqaha') have traditionally considered their domain of fiqh as providing legal norms 
and rulings on constitutional and public law questions such as the duties and responsibilities of rulers, distribution of powers, taxation, administration of justice, and appointment of officers. But figh by its nature has to engage with the wider social reality, which explains why juristic writings on this subject frequently take for granted the prevailing political system of their time. As explained by later jurists the earlier writings tended to focus on the caliphate as the representative polity. Some later (and even contemporary) jurists went so far as to criticise earlier theorists for not adapting to social reality, for writing about the historical caliphate in the age of modern democratic sovereign nation-states. Rather these later jurists insist that we should speak about democracy, the rule of law, constitutionalism, and other such 'modern' principles of governance. Yet in doing so it appears that most later jurists take the present 'modern' system for granted, and ignore that the system itself may change - so how different are they from the earlier jurists?

\section{The Concept of Siyāsah ${ }^{3}$}

There is no one Arabic word that could adequately capture the word 'politics'. This word itself, from the Greek word polis, designates city, and thus politics is that which pertains to city life - which in the Muslim historical context is designated by the term madinah. This was seen as inescapable because man is by nature considered to be social and political animal, not only because of his proneness to corruption (which calls for the need for law and regulation) but also because of his dependency on others. Man as a "political animal" following the Greeks is construed as al-hayawān al-madan̄̄, literally the "city animal" or urban creature.

The term for governance of political society is siyassah. Etymologically it derived from the act of grooming and training a horse; its earliest use in Arabic is siyāsat al-khayl, grooming and managing horses, ${ }^{4}$ the $s \bar{a}$ 'is being the groom who cares for and looks after horses. Later siyassah evolved to denote at least four things: statecraft, punishment, governance, and politics. ${ }^{5}$ The earliest use in Islamic sources of its root S-W-S in the sense of politics and leadership of the community is in the hadith where the Prophet Muhammad (may peace and blessings be on him!) stated: "The Israelites used to be led by prophets [kanat banū isrā' $\bar{l}$ l tasūsuhum al-anbiy $\bar{a}$ ']; whenever a prophet died, another succeeded him. After me, no prophet [shall succeed me], but there will be many deputies [khulafä']" ${ }^{6}$ In essence, siyassah is about governance of society to ensure the well-being and welfare of people, and ultimate happiness (both in this life and the next). In its meaning of both politics and statecraft, there existed three main approaches in classical Islam: - that of the jurists; - that of the philosophers (falāsifah); and - that of statesmen with the genre of 'Counsel' or 'Advice to Rulers' which drew from both the Hellenic and Iranian (andarz) traditions (see 
below). Here we are concerned primarily with the first two, the juridical and philosophic approaches. Traditionally siyāsah was not included as a sub-topic of fiqh, which typically covered the topics of purification, prayer, fasting, alms-tax, pilgrimage, transactions, marriage and punishments; rather discussion of siyāsah was scattered inter alia within other theological and ethical literatures. According to Bernard Lewis four meanings may be distilled from the various literature on siyāsa: (1) statecraft, (2) politics; (3) punishment; and (4) siyāsah shar 'iyyah. ${ }^{7}$

Muhammad Khalid Masud holds that "the doctrine of siyasa in Islamic law allowed a powerful role to the ruler, but it could not develop it into an institution. The modern nation-state replaced the personal concept of governance, and bestowed upon the institution of state complete sovereignty as embodiment of the nation. This development posed new questions to the doctrine of siyasa. Who has sovereignty?... Who has the powers of discretion in matters of public interest?" 8 Kalid Masud further asserts that "the duality of siyasa and shariah as a tension between theory and practice is over exaggerated". 9 The need to establish a connection between these two domains has been on the agenda of many contemporary scholars. Mohammad Hashim Kamali even sees in this duality the very root and basis of the theoretical orientations of $u s ̦ \bar{l} l$ al-fiqh (roots of jurisprudence)..$^{10}$ As will be explained further below, numerous mechanisms have been adopted by which siyāsah is made subordinate to Sharí' $a h$; in short, this distinction does not equal separation. The crisis and dilemma of modern Islam has been either to distinguish and separate the two, or to recognise no distinction at all. The latter is evident in the declaration by the President of the Egyptian People's Assembly in 1982 that: "until the end of the nineteenth century, Islamic Sharī'ah alone governed Arab states!" - a declaration which is overwhelmingly contradicted by both normative scriptural and scholarly postulates as well as historical precedents. ${ }^{11}$ The former is seen in how attempts have been made to confine the Shari' 'ah to no more than the private, personal domain, on the grounds that public life is the domain of siyassah-a proposition which brings Islam squarely within European Enlightenment secular tradition. That there have been significant overlaps between Sharī 'ah and siyāsah therefore adds to the futility of a rigid separation between the two.

Various writings in the pre-modern and classical period were produced on siyāsah as statecraft itself, and this typically assumed the form of ethics of rulership and statecraft, designated by the genre of "mirror for princes" or "advice to rulers". This significant literature included manuals such as the Tāj al-Ṣalāțin (Crown of the Rulers) by Bukhārī al-Jawharī, Bustān al-Șalātịn (Garden of the Rulers) by Nūr al-Dīn al-Rānirī, Nașịhat al-Mulūk (Counsel for Kings) by Abū Hāmid al-Ghazālī, the anonymously written Baḥr al-Fawā'id (The Sea of Precious Virtue), and Sirāj al-Mulūk by al-Turțīshī. These works 
either implicitly acknowledge the authority of Shari' $a h$, or when incorporating traditions predating Islam, integrated them into Islamic discourse. One famous concept was the notion of the 'Circle of Justice' expressed in the formula, "There can be no government without men, no men without money, no money without prosperity, and no prosperity without justice and good administration". ${ }^{12}$ In other words, the diversity of Muslim experiences and their intellectual and cultural legacy inherited from other civilisations became integrated into Islamic civilisation, enriching and enlivening its discourse.

We submit that one reason that siyassah was able to exercise independence from the Shari' 'ah has partly to do with the fact that there was no need for the Shari' 'ah to fully submerge and subjugate siyāsah. According to Noah Feldman, the classical arrangement of Muslim "constitutional" order relies on the balance of power between the class of scholars and the class of rulers. ${ }^{13}$ It is true that there have been instances when the rulers have things run their way. Once the Umayyad caliph "Abd al-Malik (rg. 64-85 AH) told a Meccan congregation at the start of his rule that "anyone who after today says to me, "be conscious of God", I will have him beheaded". ${ }^{14}$ These and various other examples go a long way to show that there have been times when siyāsah postulations override the Sharì' $a h$. But - and what an important "but" it is! - none of these episodes evolved into a full-fledged theory by which the precedence of siyāsah over Sharī 'ah is justified and normalised, or even worse, when Shari 'ah is urged to conform to or "adapt" to a world and social reality shaped and defined by siyāsah. As Ovamir Anjum aptly observes, "whereas 'irreligion' and disbelief are far from absent in Islamic history, especially among the ruling and intellectual elite, [there is] no evidence of a sustained discourse in medieval Islam, either by the 'ulama' or the practitioners of statecraft, that rejects reference to Islam for legitimation and postulates an alternative." 15

Now this crucial point of the absence of a full-fledged theory justifying the preponderance of siyāsah over Sharí' $a h$, brings us to our chief focus, namely the constitutional dilemma of the modern Muslim world. The constitutional dilemma of the modern Muslim world lies in its struggle to find a place for "Islam" or "Shari' 'ah" in the workings of the modern constitutional democratic state. This state for all intents and purposes is a "political" construct, that is to say it is siyāsah in its essence. Indeed, we may extend the argument further and claim that the modern state is a 'corporatised' version of siyassah, and here is where the problem starts. Whereas in juridical literature siyāsah referring to the ruler's discretion is identified with the person of the ruler, the same is not true in the case of the state. After all, the ruler as the personification of government or head of state is himself considered part of the state, not synonymous with it. In other words, how could the Shari 'ah accommodate the modern state when the starting point is already that siyāsah should take precedence? Instead of siyāsah being a 
supplement to Shari' 'ah, the scenario today is exactly reversed: that the Shari 'ah is now seen as supplementary to the corporate siyassah. One consequence of this has been the transformation of the Shari'ah itself, whereby among other things Shari'ah vocabularies have been transmuted to convey siyāsah-centred meanings. Thus, the term for 'community of believers' or ummah made its first modern appearance as a political community of a nation-state in the five-article 1938 Constitution of Kuwait, the first article of which derives the powers of the government from the ummah, meaning the nation. In so doing, the ummah has been confused with ra iyyat, the subjects of the kingdom as referred to in traditional public law and statecraft literature. ${ }^{16}$

The jurists were concerned with establishing the ethico-legal rules and guidelines by which the affairs of the Muslim political community could be maintained. However the philosophers had a different concern, since their focus was more on the "good life": just as they delineated at the level of ethics the virtues which man may attain by way of potential, likewise they pursued the idea of the "virtuous city" which results from the combination of "virtuous persons" living in the same community. This is not to deny that the jurists were essentially concerned with the "good life"; rather their concern was subsumed and implied in their discourse, in contrast from that of the philosophers who made it upfront and explicit.

Why is this reconciliation significant? First, the focus on individuals should be given a primary role in the analysis of political regimes, as well as their transformations and changes. This can be known by looking at how both the jurists and philosophers have explored the "technologies of the self" (borrowing M. Foucault $)^{17}$ at their disposal, namely: ethics (akhlāq) and economics for the philosophers, and jurisprudence ( $f i q h)$ for the jurists (broad enough to encompass 'ibādāt, mu'àmalāt and munākahāt), which could further incorporate elements of Sufism (tasawwuf). By way of comparison, what the jurists sought to achieve through 'ibādāt and munākahāt, the philosophers sough to achieve through ethics and economics (understood literally and in its original sense as "management of the household") - understood to be of a practical nature. In both the approaches of the jurists and the philosophers, the theoretical framework which makes practical living possible was also carefully delineated. In the case of the jurists this is accomplished through creedal theology ('aqidah, and the science that emerged from it variously known as 'ilm al-kalàm, uṣül al-dìn, and 'ilm al-tawhìd), whereas the philosophers accomplished this by dividing the sciences into theoretical and practical philosophy, so that the questions which were subsumed by the jurists under theology, they subsumed under "theoretical philosophy" ${ }^{18}$ It will be also be seen why, in the juristic deliberation on siyāsah, they were not too reluctant to acknowledge the authority of de facto rulers, namely because their "technologies of the self" still remained within Sharī'ah dominion. As long as the Sharī'ah 
continues to enjoy this privilege, the ruler is allowed to exercise limited spheres of competence.

Second, and flowing from the first, once the two modes of fashioning the human subject in political regimes are clearly understood, this may pave the way towards understanding various other alternative ways by which the human subject can be shaped, and which stand in contrast to the models we find in the legal and philosophical approaches to siyāsah. These alternative models may involve institutional structures and socio-political conditions which could effectively subject the person to other forms of self-technologies.

Thirdly, and by way of practical implications, the analyses arrived at through comparing the legal and philosophical approaches to siyassah can then be used as a tool for the analysis of constitutional shifts and transformations within the political community, to be able to predict the political, constitutional and legal trajectories that will emerge along the way. It will be shown how the prevailing system which many jurists today strive so hard to "accommodate" and claim that we should "adapt" to, is in fact deeply problematic. In doing this, the efforts towards "reforms" by legal modernists and the so-called "reformists" among the jurists will be scrutinised. It will be seen how they effectuated reforms which in fact not only fail to answer various constitutional quandaries vexing Muslim - nay, global - society, but also pave the way towards undermining the Shari' ah from within; which can nevertheless be rectified through insights into the philosophical dimension. "He who fights with monsters should look to it that he himself does not become one," warned the German philosopher Friedrich Nietzsche. "And when you gaze long into an abyss, the abyss also gazes into you." The juristic approach, in "adapting" to present realities, should be cautioned lest it plunges deep into the abyss.

\section{The Jurists and Their Siyāsah}

A historical survey of the juristic treatment to siyāsah suggests many pictures. In the earlier period the 'Abbasid Persian secretary Ibn al-Muqaffa' (d. 756) penned his Risālah fi'l-Sahābah (Epistle on Royal Companions), in which he proposed that the caliph be the final authority to interpret the Shari' 'ah. Even the 'ulama', whom he termed ahl al-figh wa'l-sunnah wa'l-siyar wa'l-nașīha, should be functionaries of the caliph and be incorporated into the state apparatus. But his proposal fell on deaf ears: the 'Abbasid caliph al-Manșūr did later ask the leading jurist, Mālik ibn Anas, who authored the early legal compendium Muwațta, if this work could be imposed as the applied law of the land - a proposal which Imam Mālik himself declined on account that the work merely represented his own personal views with which others may disagree. ${ }^{19}$

The failure of this attempt to grant the caliph authority to interpret the Shari' 'ah 
meant that a distinct domain has to be recognised by which the ruler could legitimately exercise power within the legal framework of Shari' $a h$. That domain was the siyāsah. The leading jurist Ibn Idrīs al-Shāfi'ī in an attempt to preserve the Shar' 'ah as upheld in the nușuṣ (texts) and ijmā' (consensus) from manipulation by political rulers even wrote so strongly against juristic preference (istihsānn), a recognised method in Islamic legal methodology, and equated it with caprice and arbitrary tampering with the Sharī $a h .^{20} \mathrm{Al}-\mathrm{Sh} \overline{\mathrm{f}} \mathrm{i}{ }^{\prime} \overline{1}$ even maintained that "there is no siyāsah [properly speaking] except what is in conformity with the shar.".'11 In the Hanafi school, following al-Marghinānī in the twelfth century, the jurists equate $t a$ 'zi $\bar{r}$ with siyassah, thereby laying the foundations for a special form of siyāsah shar 'iyyah that encompassed the siyāsah within the shar 'iyyah. The first monographs on the siyāsah shar 'iyyah within the Hanafĩ school were written in the fifteenth century. ${ }^{22}$ Another means by which siyāsah was recognised as part of Shari' 'ah was through the concept of mașlahah (public interest). ${ }^{23}$ The very fact that this notion is incorporated as maslahah implies that the Shari 'ah remains the standard to evaluate right and wrong. Yet this is a far cry from surrendering the authority to define Shari 'ah, much less the right to decide and determine right and wrong, to the political authority.

Nevertheless, it appears that the jurists, while recognising a practical distinction between Sharī'ah and siyāsah for the purpose of delineating spheres of competence and authority, did not actually recognise in explicit terms the distinction between the Sharī'ah and siyāsah. Thus al-Qānūjī even deemed it impossible for there to be siyāsah outside the Sharī'ah - is God's most Perfect Law so deficient (nāqișah) that it needs to be supplemented by a siyāsah external to it? Indeed, the antithesis to siyāsah shar 'iyyah is siyāsah malikiyyah, which is siyāsah kufriyyah, since in reality all that is good and just partakes of the Shar' 'ah. Accordingly all distinctions between shar'iyyah and siyassiyyah, between rational and traditional, are superfluous: "Things are either genuine (sahịh), and therefore a part of the Sharī'ah, or defective (fäsid) and therefore contrary to it." ${ }^{24}$

In actuality, the juristic approach to siyassah cannot be severed from the entire intellectual tradition upon which it rests, for it is this tradition that supplies it with the vocabularies, principles and axioms which made legal discourse possible and conditioned the parameters of its thought. This is why works of legal methodology typically begin with doctrinal-conceptual statements laying down the theoretical ground needed to pursue legal discourse. ${ }^{25}$ Similarly, the juristic approach cannot also be divorced from the spiritual path of self-purification, asceticism and mysticism, for this provides the "intensification of the Shari 'ah upon one's self" ${ }^{26}$ In this sense fiqh represents one instrument towards molding the human person to conform with his true nature, his fitrah. Even Ibn Taymiyyah's project of siyassah shar'iyyah cannot be properly understood without understanding his epistemic 
project of reconciling reason and revelation, pursued in his Dar' al-Ta 'ärud al'Aql wa'l-Naql (Averting the Conflict between Reason and Scripture). ${ }^{27}$

One aspect of the jurists' doctrinal underpinnings has been the failure to grasp properly the distinction between the unchangeable (thawäbit) and the changeable (mutaghayyirāt). Some jurists overlook matters of the unchangeable which may not be that dominant in the then prevailing doctrinal discourse, because it was historically not so much of a challenge. Thus aspects of Islam which are not changeable have only been confined to matters of belief ('aqìdah) and worship ('ibādāt). Instead of grasping a connection between the unchanging and the changeable and making the former the basis for understanding the latter, such an approach effectuates a radical disjuncture between them. Nevertheless, there have been attempts among jurists to circumvent such a strict dichotomy, such as Rashīd Riḍā's refusal to allow the massive overhaul of the family institution by state legislation, arguing that marriage constitutes part of the 'ibādāt, and hence is included as among the unchangeable things. ${ }^{28}$ 'Abd Allāh bin Bayyah in his short treatise explains that among the unchangeable things include the nature of the human..$^{29}$ As we will see when discussing the philosophers below, it is this very issue which they take into account in order to elaborate its relationship with the political regimes. The juristic approach is confronted with a dilemma, for the granting of concession to rulers on the ground of siyassah shar iyyah is a double-edged sword: it could pave the way towards a Shari 'ah that is more "engaged" and "adaptive" to social reality, or it could the open the door towards authoritarian totalitarianism. The latter case is especially true with regards to how colonial rule was justified in British India under its British governor, Warren Hastings. Hastings was irked by what he saw as the "leniency" of the Shari' 'ah (note the contrast with modern-day perceptions) wherein punishment may only be inflicted with the most stringent of conditions. Thus he sought recourse to the jurists and their doctrine of siyassah shar 'iyyah on the ground that it provided "discretion" for the ruler. ${ }^{30}$

A particular point of critique of the jurists is their seeming concession to political regimes. The Hanafĩ consensus in British India decided that the Raj formed part of dār al-Islām, just as Shihāb al-Dīn al-Marjānī in Russia took the same view with regard the empire of the Tsars. But according to Abdal-Hakim Murad, this was only because, as delineated by the Saljuq theorists, "[Sunnism] put its trust in prudence, pragmatism, and a strategy of negotiation with the Sultan". ${ }^{31}$ This is in fact reflected in many juristic writings on military takeover (istila $\left.{ }^{\prime}\right)$ and government by force or usurpation (shawkah). In such scenarios conditions were strictly laid down as to whether the government is legitimate or not. ${ }^{32}$ In fact, as we argue below, later jurists who condemn their predecessors for succumbing to political dynasties are no different, for they are doing the same thing. 
Furthermore, the legalist revival of siyāsah shar 'iyyah has been concerned with the "compatibility" of Islam with this or that present arrangement, which may, among others involve equating fiqh $\bar{\imath}$ concepts with existing arrangements or even stating the obvious, for example that laws should be guided by moral considerations, that justice should be uppermost, and so forth. While this may play a limited role in accommodating the modern democratic nation-state and cognate ideas, it risks inability to move beyond them. As we saw above, whereas the jurists recognise a practical distinction between siyāsah and Sharī'ah, in reality there is no such distinction between the two because ultimately all that is good is by nature in conformity with the Shari' $a h$. The reformers appropriated this doctrinal commitment of earlier jurists and gave it a practical dimension, so that the political authority is now vested with the complete authority of interpreting not only the Sharì 'ah but curiously enough also what qualifies as "good". The juridical approach thus has yet to implement an approach that is not merely adaptive but rather transformational, that is to say, one which seeks to transform society and the global system instead of transforming the Sharī 'ah itself to be endowed with squarely siyāsi meanings.

It should be noted that in many nation-states, particularly where the Shari' 'ah is not recognised as law, the Shari 'ah does not really occupy much of a place, and thus even if theoretically speaking by strict Shari $a h$ standards the policies or legislation do not conform to the Shari' 'ah, they will for all intents and purposes still be applicable. This brings us to the following question: if shar ' $\vec{\imath}$ reasoning really makes little difference as to the applicability of the existing systems, what then is the whole point of justifying the latter in Islamic terms? Such justifications (or rather, accommodations), we maintain, will only find significance if they are subsumed as part of a broader project towards a new conceptual constitutional framework which advances beyond the present systems and acknowledge the reality of shifts in constitutional structure. But towards that end, it must turn to a different conception of the political in Islamic thought: that of the philosophers.

\section{The Philosophers and Their Siyāsah}

At the outset it should be made clear that unlike the legal approach, the philosophical approach does not address a specific community by way of extracting practical rules as guides to human behaviour. Rather the concern of the philosophers is to delineate the various political regimes which human societies may potentially produce as latent possibilities within the very nature of man himself. They understand siyāsah as communal political activity which is inevitable due to the very nature of the human as a political animal. Humans are in need of political life to attain to their own specific perfection, which in turn requires reciprocal aid and inter-dependency of individuals. The coming 
together of individuals results in a certain combination depending on the purpose of their coming together or association. Some people cooperate with others to fulfil basic necessities such as food, shelter or clothes. Others, whose basic needs are fulfilled, are more concerned with other things such as honour, wealth or freedom. The study of politics thus looks at the form of such combinations, and each combination may produce political regimes accordingly. Therefore, when people come together to cooperate on meeting their basic needs this results in the 'City of Necessity'. When they cooperate towards securing their freedom, this produced the 'Free City', and likewise for the other purposes motivating human communal existence.

According to Ibn Khaldūn, in the vocabulary of the philosophers siyāsah meant: ${ }^{33}$

... What is incumbent upon each of the inhabitants of the social organization with respect to his soul and moral habits that they may entirely dispense with judges. They call the social organization that obtains what is required "the virtuous city" and the rules with respect to that "the political regime". They are not intent upon the regime that the inhabitants of the community set down through statutes for the common interests, for this is something else. The virtuous city is rare according to them and unlikely to occur. They speak about it only as a postulate and assumption.

What can be discerned from this passage is that the kind of political community produced is dependent on the type and intent of individual human beings who constitute it. Now the discipline which seeks to shape and mould the individual towards achieving his virtues is Ethics ( $a k h l a \bar{q})$. It is no surprise that the science of ethics stands as the prelude and prerequisite to the science of politics - along with economics (i.e., management of the social unit), both ethics and politics are deemed part of practical philosophy. Ethics, contrary to commonplace assumptions, is not concerned with the principles of right and wrong for that role is fulfilled by doctrine and theology (at the conceptual level), and by law (both usül al-fiqh, which typically includes theological and conceptual discussions of relevance to legal theory, and juridical a hkām which propounds practical rules of conduct). Rather ethics is the "science concerned with how the human soul can acquire a disposition such that all its acts, proceeding from it by its will, may be fair and praiseworthy." ${ }^{34}$ It follows therefore that "the subject matter of this science is the human soul [i.e., not moral theories, principles and concepts, which it subsumes] inasmuch as it can proceed, according to its will, acts fair and praiseworthy, or ugly and to be condemned." ${ }^{35}$ Understood in this light, and since ethics seeks to ultimately produce the political regime "according to [the soul's] will", that is to say voluntarily, it follows that by creating the conditions by which 
individuals will voluntarily wish for something, this will ultimately produce the corresponding political regime they intend.

Despite the fact that unlike the jurists the philosophers were not concerned with practical rulings to regulate conduct, it is nevertheless significant that the Muslim philosophers (faläsifah) and philosophically-tinged thinkers explored another dimension which the Shari' 'ah rests on, namely the intellectual and conceptual basis of the Shari 'ah. According to both the philosophers and certain theologians including Abū Ḥāmid al-Ghazālī, Fakhr al-Dīn al-Rāzī and Aḥmad al-Fatanī, the governance or politics (siyāsah) is of two types: external politics (siyāsah żăhiriyyah) and internal politics (siyāsah bātiniyyah).$^{36}$ External politics relates to the policies, institutions and legislations while internal politics relates to beliefs, values and principles. The smooth operation of a political regime is only possible and sustainable when there is harmony between external and internal politics.

The historical duality between Sharī'ah and siyāsah also found its way into philosophical theory. In al-Ghazālī's theory siyāsah is classified into four categories in accordance with the influence they wield upon the elite and the multitude. The first type is that of prophetic politics which governs both the elite and the multitude both externally and internally. The second is the politics of kings and rulers which governs both the elite and the multitude but only externally. The third is the politics of the scholars and the sages which governs only the elite and only internally. And the fourth is the politics of preachers which governs only the multitude and only internally. This four-fold classification of siyāsah contrasts with the concept of siyāsah as elaborated by the jurists which only seeks to regulate siyassah at the external level. By introducing the concept of internal politics (siyāsah bātiniyyah) al-Ghazālī sought to reconcile the juristic and philosophical approaches. For al-Ghazālī, siyāsah encompasses all the practical sciences (which he contrasts with theoretical sciences, and which he equates with fiqhiyyāt): siyāsat al-nafs (self-governance), siyāsat al-badan (governance of the body), and siyāsat al-balad (governance of the community), although it is the latter that is mostly in need of fiqh. But even self-governance must also be guided by the law in order to acquire the virtues and moral habits necessary for the attainment of happiness. ${ }^{37}$

The notion of 'internal politics' enables one to conceive of the possibility of social organisation independent of state apparatus, which creates for itself the centres of authority for the community. Externally, such centres of authority typically involve state institutions including the executive, legislature and judiciary. To the extent that these institutions operate harmoniously with each other and that their authority remains intact, the constitutional stability of the country can be secured. But if fissure arises, say when an "alternative" judiciary is established, or if the 
legislature and judiciary are at loggerheads, a constitutional crisis sets in. That is why it is considered important that their respective authorities are acknowledged and be maintained in place. Yet this is only at the external level of siyassah. The question then is: does social organisation depend on external cohesion alone?

Major philosophers - al-Fārābī, Ibn Sīnā, Ibn Rushd and Nāṣir al-Dīn alṬusși - recognised that by their very nature democracies will produce within themselves many other types of "cities". The cities also evolve or devolve from one to another: thus, under conditions of poverty and destitution the community will come together to form the City of Necessity, to cooperate on having its basic needs fulfilled. But once this has been accomplished it is natural that they wish to pursue their own individual goals, and that requires freedom, hence it brings about democracy. ${ }^{38}$

Philosophers differ from the jurists in their approach towards siyāsah. In contrast to the approach which divides into the three-parts of creed, law and spirituality, the philosophers divide all the sciences into two: theoretical philosophy and practical philosophy. This two-fold division stems from the twofold nature of the human soul: one speculative the other practical. The theoretical or speculative philosophy embraces metaphysics ("what lies beyond the physical'), mathematics, and natural sciences. Metaphysics in turn is divided into two: theology or the "knowledge of God and those brought near His presence, Who by His command became the first principle and cause of other existent beings, such as intelligences and souls and their judgments and actions"; and primary philosophy being "knowledge of universal things, the state of existent beings from the standpoint of their being existent, such as unicity and plurality, necessity and potentiality, anteriority and phenomenality...", which includes knowledge of prophecy (nubuwwah), the imāmate, the circumstances of life in the Hereafter, and similar topics. ${ }^{39}$ As can be seen by this classification, what the jurists subsumed under creedal theology as their foundation and starting point for legal theory, the philosophers subsumed under theoretical philosophy. It is these premises which then became the philosophers' basis for venturing into the practical affairs of life conduct - practical philosophy subsuming ethics, economics and politics.

The whole point of philosophy is precisely to deal with the unchangeable things, which explains why Nāṣir al-Dīn al-Ṭuṣ̣i excludes jurisprudence and law from his inquiry, and also why his economics and politics, which by modern standards are empirical par excellence, are dealt with in conceptual rather than empirical terms. Thus he stated: "The speculation of a philosopher is confined to examining the propositions of intellects and investigating the universalities of things, and these are not touched by decay or transience, nor are they obliterated or replaced according to the obliteration of peoples and severance of dynasties." He excludes 
jurisprudence on the ground that it is "liable to change, with revolutions in circumstances, with the preeminence of individual men, the prolongation of time, the disparity between epochs and the substitution of peoples and dynasties." ${ }^{40}$

The philosophers saw falsafah as simply another way of conveying immutable truth, which is one and the same everywhere but expressed differently in religious discourse. Al-Fārābī notes that "theoretical positions in religion have their proofs in theoretical philosophy. In religion they are taken without proof." ${ }^{11}$ Antony Black rightfully observed that al-Fārābi significantly "located the differences between types of political society in social attitudes rather than in constitutions." ${ }^{" 42}$ It should be noted that earlier philosophers like al-Fārābī and Ibn Sinna wrote before the later evolution of Islamic theology whereby these two disciplines became virtually indistinguishable (as Ibn Khaldūn observed ${ }^{43}$ ), so well exemplified in the thought of Fakhr al-Dīn al-Rāzì. This idea of changes in social attitudes brings us to another insight of the philosophers drawn from the science of history of civilisation. We include this here, heeding Ibn Khaldūn's insight that History should be treated as a branch of philosophy insofar as it concerns itself with fundamental principles, being in fact rooted in philosophy. In his Muqaddimah he explains the two pivotal forces driving human civilisation: 'așabiyah (group solidarity) and mulk (power or sovereignty) ${ }^{44}$

Seen in this light the order now is reversed: whereas in the past, the Shari 'ah was less territorially bound and constrained being focused on the worldwide ummah, while the philosophic approach to siyāsah was confined to the territorially defined polis. Now the approach that we have envisaged anticipates a reversal: it is currently the philosophical approach that will be worldwide and universal, while the juristic approach - no thanks to the curious permutations it has been subjected to by later jurists - will be the one that is territorially delimited. The matter does not end there, for it is on the basis of the philosophical redemption of the 'good human being', the 'good society' and the 'good political regime' that the dry legalism which has characterised siyassah will be resuscitated and its soul and spirit enlivened with a new breath of life.

\section{Legal vs Philosophical Siyāsah in Conflict?}

Recently scholars have highlighted an alleged essential incommensurability between the jurists and philosophers. Fauzi Najjar in his article "Siyasa in Islamic Political Philosophy" distinguished the approach of the jurists and philosophers by asserting that the jurists "could in no way subject the fundamental assumptions of their thoughts to critical analysis." Thus the jurists "were bound more by theological rather than rational considerations". Consequently it appeared as if the philosophers dispensed with their religious basis, which is not the case at all. He even claims that the philosophers establish siyassah as an independent 
discipline separate from religion, as if he was unaware of the classification of the sciences. Najjar claims that the "philosophers subjected to severe scrutiny what the jurists took for granted", unaware that ușül al-fiqh begins where kalām leaves. ${ }^{45} \mathrm{He}$ further maintains that al-Fārābī's identification of the ruler with the Prophet (i.e. the one who receives Revelation) represents but a "concession to orthodox Muslim sentiment". ${ }^{46}$ The philosophers, he claims, believed that "revealed dogma is nothing but an inferior form of metaphysical truths useful for the masses". ${ }^{47}$ In his final verdict the philosophers "[subordinated] religious Law to politics (siyasa)". ${ }^{48}$

Similarly Antony Black observes that al-Fārābī and Ibn Sīnā "seem to have regarded Philosophy as an alternative articulation of Islamic postulates, more promising than what they saw as the crass popular narrativism of the Reporters, and, indeed Jurists." ${ }^{" 49}$ Ovamir Anjum in Politics, Law and Community in Islamic Thought claims that the differences between the polis and the ummah cannot be easily brushed aside, asserts that in medieval Islam "law trumped politics." ${ }^{50} \mathrm{We}$ observed above that this term ummah for 'political community' made its first modern appearance in the five-article 1938 Constitution of Kuwait, which derives the powers of the government from the ummah in the meaning of nation; ${ }^{51}$ here the ummah or community of believers is confused with ra'iyyat or subjects of a kingdom. ${ }^{52}$

It is also widely alleged that the Islamic philosophical approach tends to appropriate much from Hellenic philosophy, and that its 'Islamicity' is suspect. Thus we find Sayyid Quṭb castigating al-Fārābī, Ibn Sīnā and Ibn Rushd as "no more than a shadow of the Greek philosophy and has no relation to the true Islamic philosophy". ${ }^{53}$ Nor has the tension between Sharī'ah and siyāsah been adequately diagnosed as the tension between ideal and practice, between theory and reality. Muhammad Khalid Masud reminds us that such a stark dichotomy between the two is seriously exaggerated. ${ }^{54}$

The approaches even differ remarkably between Muslims and Western thinkers. Whereas many Muslims today perceive the juristic and legal tradition as being the most faithful representative of Islam, and privilege Shari 'ah discourse as the most normative and preferred form of Islamic intellectual expression while censuring the philosophical approach as no more than Greek accretions into Islamic civilisation, Western authors adulate the philosophical stream of rational thought as the 'golden age' of Islam, while seeing in the juristic literature a legalist even authoritarian excess of the same community. A. Black even claims that "the decline of the Caliphate coincided with the Golden Age of Islamic philosophy and humanism." ${ }^{55}$ Even more unacceptable is the claim that despotism and authoritarianism in the Muslim world has been attributed to the 
fact that Aristotle's Politics was not translated into Arabic until recently, a work which supposedly was appreciated in Europe thereby giving birth to the doctrine of separation of powers as found in Baron de Montesquieu in the $18^{\text {th }}$ century. ${ }^{56}$

\section{Reconciling the Two Approaches}

From such premises it follows that rulings of figh on siyassah must be based on the explicit acknowledgement of the evolution and transformation of constitutional orders, so lucidly explained by the philosophers. It must be able to recognise the various varieties of "sub-regimes" residing within a single political regime, as with the case of the philosophers' interpretation of democracy as precisely the city in which many other "cities" reside. Thus, in a typical democratic state, various other types of "states" also exist, in addition to the fact that other states may also find their presence in that same state. This contention is vindicated historically by the Muslim experience with colonialism which often began innocuously as trade and commercial ventures, as in the case of the British Empire through its East India Company (EIC) in the $19^{\text {th }}$ and $20^{\text {th }}$ centuries. ${ }^{57}$ Yet these examples are by no means purely "historical": the same method is likely to recur or is now occurring.

That the economic order of the political community has yet to be recognised in contemporary Islamic jurisprudence as part of the constitutional makeup of the state is one of the most unfortunate shortcomings of contemporary juristic literature on siyāsah. Of course, this question did not vex classical authors, simply because earlier jurists were not confronted with a major challenge facing contemporary societies - namely the corporation as a powerful impersonal entity and financial bloc which may even subjugate the state. We take issue with the claim that the ummah has any 'legislative' (tashrī) authority, since this is the exclusive prerogative of the Lawgiver. Yet what if the ummah is made the locus of interpretive authority? Let us take education as an example. That education - which properly was aimed at producing good human beings, and later changed its objective to produce a good "citizen" 58 - now has come to be aimed at producing "good employees" or "employable graduates". This provides a clue as to changing social attitudes, which in the long run could bring about a change in the constitutional makeup of the polity. Moreover, many aspects of self-technologies which were once the domain of spirituality and religion are now being appropriated as part of "business training" programs, including building self-confidence, conflict resolution, crisis management, employee productivity, etc.

The sought for reconciliation of legal and philosophical siyassah with its refocus on the primacy of individuals brings us to several other dimensions only mentioned briefly here. First: is the role group feeling ('asabiyyah) serves as foundation for the political community, and to analyse this concept 
in relation to the proposed synthesis between law and philosophy. Second: Does the ruler's commitment to maslahah mean that the state must be directly involved in welfare, or would it merely facilitate the conditions for the private sector to flourish in order to fulfil the intended mașlahah? Thus, in elaborating constitutional law for today, such factors must be taken into account. Thirdly: in constitutions throughout the world various provisions are in place to identify the basic characteristic of the said political community; including provisions for official language, official religion (in certain cases, even 'state' religion), or the ideology of the state (Turkey's constitution explicitly calls itself secular, just as India's constitution declares itself socialist). However these provisions were inserted when the values and principles adopted were still upheld by the generality of people if not the majority. But this ignores the fact that in future certain truths it upholds may no longer be valid due to various transformations. A written constitution no doubt gives a certain degree of objectivity, clarity and certainty over important matters when governing and administering the state. But it nevertheless compromises the element of flexibility and dynamism of those societies without a written constitution.

\section{Conclusion and Recommendations}

The Shari' $a h$ as elaborated and applied in substantive law (fiqh) may continue its role in providing the moral-legal framework for public and constitutional law of contemporary Muslim states. It could even advance principles and rulings to define the powers and authority of the offices of the state. By incorporating insights from the Islamic philosophical tradition, the juristic approach would remain faithful to immutable principles of Islam, avoid succumbing to presuppositions which justify the modern state that are in any case problematic, and transcend the boundaries of nation-states thereby enabling the community to act truly globally. These insights from the philosophers, in turn, must be harmonised with contemporary theology ( $\mathrm{ilm}$ al-kaläm) which is moving towards a "new theology" (al-kalām al-jadīd).

There is no doubt that the Shari' $a h$ will continue to play a pivotal role in the lives of Muslims, for at the most basic level it continues to be the major repository of values and praxis shaping religious life. Yet if fiqh as the traditional medium of legal expression and articulation of Shari' 'ah norms is to be able to play a meaningful role in constitutional law and governance more adequately in the present time, it must be able to accommodate the dynamism of global society which involves constitutional shifts within states, even when the official, written constitutions do not reflect them.

Towards fulfilling this role, we propose that: 
- A conceptual framework for analysing the constitutions of contemporary Muslim states should be produced based on juridical-philosophic synthesis on siyasah, so that each state can only be understood as part of and in reference to Islamic civilisation as a whole, from whose philosophy and history these states cannot be divorced.

- The said framework must be able to accommodate or explain - without necessarily conceding to - present realities, such as democracy, the nationstate and the market from its own principles and premises.

- The said framework must offer the conceptual tools to analyse constitutional shifts and transformations within states which can be applicable ultimately to other states.

\section{Notes}

* Tengku Ahmad Hazri is Research Fellow at IAIS Malaysia. After obtaining his law degree, LLB (Hons), he was attached to the International Movement for a Just World (JUST). Later he pursued his graduate studies at the International Institute of Islamic Thought and Civilization (ISTAC), Kuala Lumpur. He would like to express his deep thanks and acknowledgment to Dr Karim Crow for meticulously evaluating the original draft and offering insightful comments and suggestions.

1. For our conceptualisation of 'two constitutions', consult our previous study: Tengku Ahmad Hazri, "Constitutional Governance and the Future of Islamic Civilisation," ICR 4 no. 4 (October 2013) pp. 601-614, at 610-612, where we define the relationship between the written and the unwritten constitution on the basis of six salient components of a modern written constitution: (1) establishes a 'state; (2) regulates the organs and institutions of government; (3) is the supreme law of the land; (4) creates citizenship, and by extension also (5) creates a nation; and (6) protects the fundamental rights of the citizens. This offers an analytical framework for addressing constitutional challenges in the Muslim world so that various issues may be subsumed under one (or more) of these components. Thus, by the standard of their written constitution the people are one nation-state ( 55$)$, but at the level of the unwritten constitution this so-called 'nation' is a loose combination of tribal groups with their own centres of authority whereby each might be seen as nations in their own right.

2. Syed Muhammad Naquib al-Attas, Islam dalam Sejarah dan Kebudayaan Melayu [Islam in Malay History and Culture] (Kuala Lumpur: Penerbit Universiti Kebangsaan, 1972). This notion has parallels with the concept of internal governance' (siyāsa bātiniyya) of al-Ghazālī and al-Rāzī as explained below.

3. For a brief justification for treating siyāsah (politics) as the domain of constitutional law, see Tengku Ahmad Hazri, "Constitutional Law as EthicoPolitical Discourse", ICR 4. No. 2 (April 2013), 312-316,

4. Bernard Lewis, "Siyasa" in A.H. Green (ed.), In Quest of an Islamic Humanism: Arabic and Islamic Studies in Memory of Mohamed al-Nowaihi (Cairo: The 
American University of Cairo Press, 1984), 3-14 at 3.

5. Ibid.

6. Narrated by Aḥmad in his Musnad, Bukhārī (Kitāb al-Anbiyāa'), and Muslim (Kitāb al-Imārah); cited by Ovamir Anjum, Politics, Law and Community in Islamic Thought: The Taymiyyan Moment (Cambridge: Cambridge University Press, 2012), 59.

7. Bernard Lewis, "Siyasa".

8. Muhammad Khalid Masud, "The Doctrine of Siyasa in Islamic Law", Recht van de Islam 18 (2001), 1-29 at 22.

9. Ibid., 23.

10. Mohammad Hashim Kamali, Principles of Islamic Jurisprudence (Cambridge: Islamic Texts Society, 2003), 502-503.

11. Said Amir Arjomand, "Introduction" in Said Amir Arjomand (ed.), Constitutional Politics in the Middle East: with Special Reference to Turkey, Iraq, Iran and Afghanistan (Oxford and Oregon: Hart Publishing, 2008), 2.

12. Linda T. Darling, "Islamic Empires, the Ottoman Empire and the Circle of Justice" in Said Amir Arjomand (ed.), Constitutional Politics in the Middle East: with Special Reference to Turkey, Iraq, Iran and Afghanistan (Oxford and Oregon: Hart Publishing, 2008), 11-32.

13. Noah Feldman, The Fall and Rise of the Islamic State (Princeton: Princeton University Press, 2012).

14. Abdelwahab El-Affendi, Who Needs an Islamic State? (London: Malaysia Think Tank, 2008), 77-78. The point being the caliph's warning religious persons not to criticise his deeds by pious reminders, for starting with the Umayyad rulers the 'Islamic polity' was captured by the autocratic 'state' and constrained to serve it.

15. Ovamir Anjum, Politics, Law and Community in Islamic Thought: The Taymiyyan Moment (Cambridge: Cambridge University Press, 2012), xiv.

16. Said Amir Arjomand, "Introduction" in Constitutional Politics, 2-4.

17. Wael B. Hallaq, The Impossible State: Islam, Politics and Modernity's Moral Predicament (Columbia: Columbia University Press, 2013), chapter 5, "The Political Subject and Moral Technologies of the Self", 98-138.

18. Consult e.g., Nāșir al-Dīn al-Ṭ̂̄īì, Akhlāq-i Nāṣirī, translated from the Persian by G.M. Wickens as The Nasirean Ethics (London: George Allen \& Unwin, 1964), 26-29.

19. Muhammad Qasim Zaman, Religion \& Politics under the Early 'Abbasids: The Emergence of the Proto-Sunni Elite (Leiden: Brill, 1997), 81-84.

20. Mohammad Hashim Kamali, Principles of Islamic Jurisprudence, 502.

21. Fauzi M. Najjar, "Siyasa in Islamic Political Philosophy" in Michael Marmura (ed.), Islamic Philosophy and Theology: Studies in Honor of George F. Hourani (New York: SUNY Press, 1984), 92-110 at 95.

22. Baber Johansen, Contingency in a Sacred Law: Legal and Ethical Norms in the Muslim Fiqh (Leiden: Brill, 1998).

23. Muhammad Khalid Masud, "The Doctrine of Siyasa in Islamic Law", 7-10.

24. Fauzi M. Najjar, "Siyasa in Islamic Political Philosophy" at 96.

25. Wael B. Hallaq, Shari'a: Theory, Practice, Transformations (Cambridge: Cambridge University Press, 2009), 79. See also Anver M. Emon, Islamic Natural Law Theories (Oxford: Oxford University Press, 2010), which discusses 
theories of natural law in Islam and the 'Euthyphro dilemma' but referring mainly to works of $u$ șül al-fiqh.

26. Syed Muhammad Naquib al-Attas, Islam and Secularism (Kuala Lumpur: International Institute of Islamic Thought and Civilization (ISTAC), 1993, $2^{\text {nd }}$ ed.), 121.

27. Ovamir Anjum, Politics, Law and Community in Islamic Thought, 26.

28. Aharon Layish, "The Contribution of the Modernists to the Secularization of Islamic Law", Middle Eastern Studies 14 (1978), 263-277.

29. Shaykh Abdullah bin Bayyah, Islamic Discourse: Between the Conclusive and the Variable (Abu Dhabi: Tabah Foundation, 2009), 23-25.

30. Muhammad Khalid Masud, "The Doctrine of Siyasa in Islamic Law", at 17-18.

31. Abdal-Hakim Murad, "Bombing without Moonlight: The Origins of Suicidal Terrorism", available online at http://www.masud.co.uk/ISLAM/ahm/ moonlight.htm.

32. Mohammad Hashim Kamali, "Political Jurisprudence in Islam: Historical and Contemporary Perspectives", presentation at the seminar on New Conversations in Islamic and Christian Political Thought, University of Oxford, 14-15 September 2013. We would like to thank Prof. M. Hashim Kamali for making his article (in draft form) available for our use.

33. Charles E. Butterworth, "Ethical and Political Philosophy" in Richard Taylor and Peter Adams (eds.), The Cambridge Companion to Arabic Philosophy (Cambridge: Cambridge University Press), 266.

34. Nāṣir al-Dīn al-Ṭūsī, Akhlāq-i Nāṣirī, 35.

35. Ibid.

36. Antony Black, The History of Islamic Political Thought: From the Prophet to the Present ( $2^{\text {nd }}$ Edition, Edinburgh: Edinburgh University Press, 2013), 102-103, 129-130; al- 'Ālim al-Allāmah az-Zakī Asy-Syeikh Wan Ahmad bin Muhammad Zayn al-Fathan̄̄, Hadīqatul Ažhār war Rayāhīn ['The Garden of Flowers and Fragrances'] (Kuala Lumpur: Khazānah Fathanīyah, 1998), 194.

37. Fauzi M. Najjar, "Siyasa in Islamic Political Philosophy" at 99.

38. Ibn Rushd [Averroes], Averroes on Plato's Republic (Translated, with an Introduction and notes by Ralph Lerner) (New York: Cornell University Press, 1974), 111-112.

39. Nāṣir al-Dīn al-Ṭūsī, Akhlāq-i Nāṣirī, 27.

40. Ibid, 29.

41. Osman Bakar, Classification of Knowledge in Islam (Kuala Lumpur: International Islamic University Malaysia, 2006).

42. Antony Black, The History of Islamic Political Thought: From the Prophet to the Present (Second Edition) (Edinburgh: Edinburgh University Press, 2013), 69.

43. Ibn Khaldun, The Muqaddimah: An Introduction to History, translated and introduced by Franz Rosenthal, with a new introduction by Bruce B. Lawrence (Princeton and Oxford: Princeton University Press, 2005), 389; see also Ayman Shihadeh, "From al-Ghazālī to al-Rāzī: $6^{\text {th }} / 12^{\text {th }}$ Century Developments in Muslim Philosophical Theology", Arabic Sciences and Philosophy, vol. 15 (2005) 141-179.

44. Ibid, 172-174.

45. Fauzi M. Najjar, "Siyasa in Islamic Political Philosophy”, at 101-109. 
46. Ibid, 108 .

47. Ibid, 109 .

48. Ibid.

49. Antony Black, Islamic Political Thought, 58.

50. Ovamir Anjum, Politics, Law and Community in Islamic Thought, 20.

51. Said Amir Arjomand, "Introduction" in Said Amir Arjomand (ed.), The Rule of Law, Islam and Constitutional Politics in the Middle East, 4.

52. Said Amir Arjomand, Constitutional Politics in the Middle East, 2.

53. Sayyid Qutb, Social Justice in Islam (Kuala Lumpur: Islamic Book Trust, 2000), 38.

54. Muhammad Khalid Masud, "The Doctrine of Siyasa in Islamic Law", 1-29.

55. Black, History of Islamic Political Thought, 57.

56. Said Arjomand and Nathan Brown, "Introduction" in Said Amir Arjomand and Nathan Brown (eds.), The Rule of Law, Islam and Constitutional Politics, 2-4.

57. Consult Wael B. Hallaq, An Introduction to Islamic Law (Cambridge: Cambridge University Press, 2009), 85-114.

58. For clear explanation, see Syed Muhammad Naquib al-Attas, The Concept of Education in Islam: a Framework for an Islamic Philosophy of Education (Kuala Lumpur: International Institute of Islamic Thought and Civilization (ISTAC), 1999). 